\title{
Menstruation: curse or blessing?
}

\author{
Lesley Smith
}

\section{Cleansing or curse?}

Menstruation in our lifetime has been commonly called 'The Curse'. Our sisters in the 16th century, however, welcomed this cleansing as a fertility sign from God, through the moon that determined the tides of all that flowed on the earth. These tides included the four humorous fluids that made up each of us and determined, by balance, the health of an individual.

Ancient medical philosophers for over 1000 years understood by observation that if a woman did not bleed each month she was unlikely to conceive. In the 16th century, women were considered to be very different creatures medically from men. Women were born with more blood in their bodies, and were colder by nature than the hotter, stronger, intellectual male. Men were also considered of higher moral character than women, being stronger in every sense.

Understanding how the female body worked was subject to considerable confusion. Despite the uteric sections of the body being quite accurately described by Soranus, for some reason it was later believed that the womb was divided into seven cells. The male cells were the three on the right and the female the three on the left. The middle cell was for a wasted egg or to grow a hermaphrodite child.

By 1545 , the widely read publication, The Birth of Mankind (believed to be published initially in Germany), clearly denied the seven-cell principle, which shortly after this time was fully accepted as a notorious mistake. The Hippocratic teachings that the male eggs lay on the right and the female on the left of the womb remained long after the 16th century. Even in these modern times, home-spun medical myths are often rooted in thinking dating back to the ancients, but still persist, over the centuries.

\section{Conception and the monthly cycle}

So let us consider a middle- or upper-class woman struggling to conceive. She would be well aware that a regular blood flow was essential. She would also have to take steps to do all she could to hold the child in the womb long enough for a live birth.

Good humoral health was considered the key, with an appropriate balance of the flows of blood, yellow bile, black bile and phlegm. If one or more humours upset the natural balance (dyscasia) it could affect menstruation. Complexions and temperature, even colour of hair, could be read as symptoms for diagnosis of a particular humour predominating. The personality may be sanguine, choleric, melancholy or phlegmatic. During conception and pregnancy the balance should be addressed by careful diet and temperature. Dirty stars were also believed to affect health adversely and were much feared, as was miasma creeping up from foul smells.

One can now easily see what was thought to be the right environment for the new Elizabethan wife eager to do her duty and conceive. A carefully balanced diet, pleasant smells and rest were good preparation for possible conception. Likewise good preparations for the 21 st century girl!

J Fam Plann Reprod Health Care 2006; 32(3): 199-200

Tutbury Castle, Tutbury, UK

Lesley Smith, Curator

Correspondence to: Lesley Smith, Tutbury Castle, Tutbury, Staffordshire DE13 9JF, UK. E-mail: info@tutburycastle.com
A rich woman who failed to have regular menses was able to consult a university-trained doctor. As part of his examinations he would have her wear a type of loincloth for some days so that discharge might be checked. The colour of the discharge would tell the doctor which humour was out of balance and then he could treat accordingly.

By today's standards the pharmaceutical treatments ranged from mad to dangerous, with some outstanding exceptions. The origins were early Greek and were in the polypharmaceutical tradition of Galen. Doctors would mix up a vast range of components (up to 100), some of which were not found naturally in the diet, and then the body could choose what it needed. Heat might also be applied by degrees from warm to blistering! Dr John Hall of Stratford upon Avon (born c.1575) made case notes about the treatment of his patients. He was a caring, capable, provincial doctor and much respected. His records show $60 \%$ of his patients were female and their treatments provide a fascinating and vital link for medical historians studying the period.

Reassurance features strongly, and we all know the healing benefits of confidence. No doubt some illnesses 'disappeared' for these reasons as much as any other and no doubt menstruation 'appeared' in the same way.

For those not able to afford a doctor, various remedies "To bring on the Flowers" can be found in household books such as Gervase Markham's, The English Housewife. He largely favoured herbal remedies but also included bleeding, vomits, poulticing and cupping for those who liked more active treatments.

There are recipes available for decreasing and increasing blood flow, stomach cramps and cleansing after childbirth. Equally, it would not take a huge amount of intelligence to work out that some of these recipes could bring on abortion, such as the one "For the delivery of a dead child".

\section{Mediaeval menstrual matters}

Arrangements for menstrual hygiene can be found clearly in the upper and rich classes. Household accounts show that there were laundresses of private linen. That linen could include menstrual cloths probably soaked in salt, washed out and hung out to dry in hot rooms over racks. I have not been able to determine if royal cloths were then sent 'down the line' for use by others, with fresh cloths being used each time by the royalty. Imagine how high on the list of paid informants these laundresses must have been when a marriage enquiry was underway!

Meanwhile, whilst linen was being held on fine belts under a shift for the rich, the less well off were not able to afford such cloths. The argument of using rags doesn't apply, since poorer people were already wearing rags as clothing, and so would not have enough to spare for this purpose. I have spent some time trying to trace what might have been used instead. The Museum of Menstruation and Women's Health website suggests the use of grass - but held in what? However, from the 13th century there is evidence of cloth being made from nettles. It is a fiddly, time-consuming process but the resultant cloth is free. The principle is that once the harness is made, it is filled with grass or sphagnum moss, which is soft, green and absorbent. Many readers will know that sphagnum moss was used to treat wounds and bedsores in the 19th century. Certainly one mediaeval historian told me she had seen the 


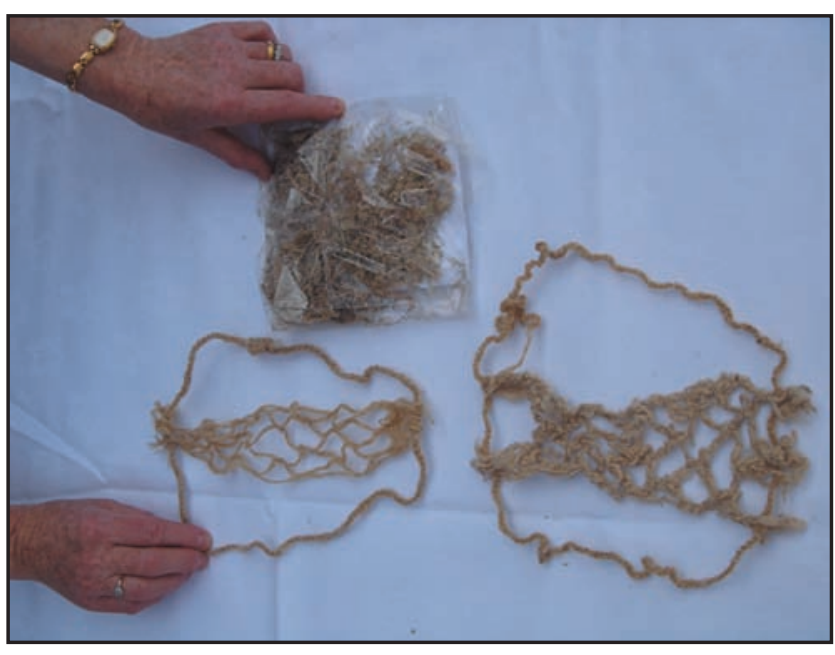

Figure 1 Two examples of menstrual harnesses woven from Jacob's wool and silk (left) and nettle fibre (right)

use of a nettle harness and sphagnum moss in records - but where? I have been searching for 2 years now for proper evidence without success.

I decided to try an experiment and invited nettle expert, Gillian Edom, to join me in my castle in Staffordshire. She showed me how to crop mature nettles, rhet (rot) them in dew or in a brook, and bring the slimy nettles in and dry them in a cellar. As Gillian was only with me for a weekend, she had brought nettles along in various stages and most kindly also brought a precious supply of the fibre.

After a few weeks drying out, elegant brown sticks remain. Inside the sticks is nettle fibre that looks exactly like sheep's wool. The fibre is boiled in a pan with wood ash (in a stocking). The smell of washing powder reminded one of the alkali present - a necessary part of the preparation. At the next stage the fibre was washed in a sieve, dried and carded just like sheep's wool.

Weaving the fibre was not an easy task. It took a local lady weaver a year in her spare time to complete the harness. She told me it was difficult because the fibres were short and broke easily, and suggested that perhaps the fibre may have had a little wool mixed in, poached from hedges. To prove the point, Nancy Simms went on and made me a Jacob's wool harness and a silk one, both in a matter of hours (Figure 1).

I am hoping to acquire some newly grown sphagnum moss, perhaps from my own Birmingham University Botanical Gardens and, yes, I do intend to wear the harness when menstruating. The used sphagnum moss will go up to the laboratories for testing and I will report on the results. Certainly the harness is comfortable, and I have worn it all day without irritation. Meanwhile, I shall be trawling the Wellcome Library for further evidence.

Finally, for those of you surprised at how able we were so long ago, I do have a photograph of a used tampon found inside an Egyptian mummy!

\section{Future articles}

Readers interested in finding out more for themselves about the topics covered in this article should consult some of the publications listed in the Bibliography.

For those with a yearning to find out more about nettles, Gillian Edom is giving two talks at the Natural History Museum in London later this year as part of the 'Be Nice to Nettles Week'!

The next article in the series on 'The French Pox' explores the arrival and impact of syphilis in English society. It also considers the role of doctors and the desperate measures taken in an attempt to control this sexual plague.

\section{Acknowledgements}

The author would like to thank the following individuals for their help and advice: Gillian Edom, Nancy Simms, Dr R Arnott, Sub-Dean of Medicine and Director, The Medical School, University of Birmingham, Birmingham and Dr G Williams, Curator, British Museum, London, UK.

\section{Bibliography}

1 Trotula (primary source). Green, Monica (ed.) (translated from the Latin). Pennsylvania, PA: University of Pennsylvania, 2001.

2 Markham, Gervase. The English Housewife 1568-1637. Best, Michael R. (ed.) (translated from the primary source). Montreal and Kingston, Canada: McGill-Queen's University Press, 1986.

3 Lane, Joan. The Patients of Dr John Hall. Stroud, UK: The Shakespeare Birthplace Trust/Sutton Publishing Limited, 1996. A lively, fascinating book showing actual published notes of John Hall with translations and comments about the medicine practised.

4 Jonhas, Richard. The Birth of Mankind. First published in English in 1540 (translated from the Latin De partu hominis, which was translated in 1532 by Christian Egenolph from a German original Der swangern Frauwen und Hebammen Roszgarten published in 1513 by Eucharius Rosslin).

5 Shail, Andrew and Howie, Gillian. Menstruation, A Cultural History. Basingstoke, UK: Palgrave Macmillan, 2005. A wide range of expert contributors made up this fascinating reference work, from Aristotle to modern times, across a spectrum of culture.

6 Hunken, Tim. "Moss" claims to be information given as informative entertainment. It succeeds! All you probably ever wanted to know about moss and its many uses including medical available at this fascinating website (http://www.rudimentsofwisdom.com/pages/ moss.htm).

7 Wellcome Library for the History and Understanding of Medicine, London, UK. Every doctor who enjoys the history of medicine should be a member.

8 Huggett, Jane. Lust 1450-1660: How to Provoke It, Restrain It and Deal with the Consequences (1st edn). Bristol, UK: Stuart Press, 1995. A small pamphlet/book, well researched and helpful.

9 Museum of Menstruation and Women's Health website (www.mum.org). Some of the contributors are specialists and it is certainly an unusual information source. How well researched the information given is I can't tell - yet!

10 Gowing, Laura. Common Bodies. Newhaven and London, UK: Yale University Press, 2003.

\section{About the Author}

Lesley Smith is an Elizabethan historian, currently studying for the degree of MPhil in the History of Medicine at Birmingham University Medical School. She has appeared in 17 television programmes including Tony Robinson's The Worst Jobs in History, and is currently working on an eight-part 1-hour major series on the Private Lives of Women.

Lesley is well known as a public speaker, and in November 2005 she spoke at The Guildhall, London, UK to an audience of more than 500 including gynaecologists, members of the House of Lords and a Health Minister on the occasion of the 75th anniversary of the fpa (Family Planning Association).

Canon Law: A mediaeval variant of 'Snakes and Ladders'

The complexities of Canon Law may be thought by some as both tedious and laborious but it is a necessary part of 15th and 16th century historical study. Ecclesiastical law had a huge impact on every section of English society and its foothold born of centuries of power. When Henry VIII finally cut the already frayed ropes with Rome, the good ship Reformation had on board an English people who would live through dramatic change.

This issue of the Journal includes a mediaeval-style board game* that is designed to demonstrate how much power Canon Law wielded even in the marriage bed, no matter how tightly the curtains were closed. However, we have little evidence of how many were pious enough to fully conform. It's a matter of conscience.

I devised this game at 2 am one morning when seeking inspiration as to how to teach such an issue whilst having fun. Sleep came at 3 am - happily. The objective of the game is to take a die, some counters and two players, and then try to reach the finish when sex is permissible. On the way, you will encounter many great political and medical milestones.

For those of you who may wonder how long the game of 'Snakes and Ladders' has been played the answer is about 2000 years! It was devised in Asia to teach people the difference between right and wrong. The British Museum has a vast and fascinating collection.

*Board game sponsored by the Journal of Family Planning and Reproductive Health Care. 